\title{
Biotransformation of carbamazepine by laccase-mediator system: Kinetics, by-products and toxicity assessment
}

\author{
Mitra Naghdi ${ }^{\mathrm{a}}$, Mehrdad Taheran ${ }^{\mathrm{a}}$, Satinder K. Brar ${ }^{\mathrm{a}, *}$, Azadeh Kermanshahi-pour ${ }^{\mathrm{b}}$, M. Verma ${ }^{\mathrm{a}}$, \\ R.Y. Surampalli ${ }^{\mathrm{c}}$ \\ a INRS-ETE, Université du Québec, 490, Rue de la Couronne, Québec G1 K 9A9, Canada \\ ${ }^{\mathrm{b}}$ Biorefining and Remediation Laboratory, Department of Process Engineering and Applied Science, Dalhousie University, 1360 Barrington Street, Halifax, Nova Scotia, \\ B3J 1Z1, Canada \\ ${ }^{c}$ Department of Civil Engineering, University of Nebraska-Lincoln, N104 SEC PO Box 886105, Lincoln, NE 68588-6105, USA
}

\section{A R T I C L E I N F O}

\section{Keywords:}

Carbamazepine

Biotransformation

Laccase

By-products

Yeast estrogenicity screen assay

\begin{abstract}
A B S T R A C T
Carbamazepine (CBZ) is one of the most detected pharmaceutical compounds around the world, with adverse human and animal health impacts in wastewater effluents. Recently, biocatalytic degradation using ligninolytic enzymes such as laccase along with redox mediators provides a promising approach for their removal from water and wastewater. However, the effects of operational parameters on biotransformation need to be investigated in order to design a robust and efficient process. In this research, central composite design was performed and analyzed using response surface methodology to study the effects of temperature, $\mathrm{pH}$, enzyme concentration and mediator concentration. The adequacy of the developed model was confirmed by the coefficient of multiple regression $\left(\mathrm{R}^{2}=75.97 \%\right)$ indicating a reasonable model for practical implementation. The results showed that performing the biotransformation at $35^{\circ} \mathrm{C}, \mathrm{pH} 6$, with $60 \mathrm{U} / \mathrm{L}$ of enzyme concentration and $18 \mu \mathrm{M}$ of mediator concentration resulted in 95\% removal of CBZ. 10,11-Dihydro-10,11-dihydroxy-CBZ and 10,11-dihydro-10,11epoxy-CBZ were identified as the major metabolites of CBZ oxidation by laccase. The estrogenicity tests indicated that the CBZ with an initial concentration of $4 \mu \mathrm{M}$ and its biotransformation products had no estrogenic effect. The successful transformation of CBZ demonstrated the potential of the laccase-mediator system for the removal of recalcitrant micro-contaminants.
\end{abstract}

\section{Introduction}

Currently, pharmaceutically active compounds (PhACs) are routinely detected at very low concentrations in the effluents of wastewater treatment plants (WWTPs) [1,2]. Since the PhACs can produce a biological effect at lower concentrations, the discharge of these compounds into the aquatic environment may pose adverse effects on the receiving ecosystem $[3,4]$. Therefore, the removal of such compounds is beneficial to the environment and human health.

Carbamazepine (CBZ), a widely used psychiatric drug, is one of the most frequently detected compounds in the surface water and groundwater that receive wastewater effluent [5]. Around $30 \%$ of the CBZ is excreted in intact form after administration [6]. CBZ is resistant to biotransformation and adsorption to sludge [7,8], which leads to poor removal in conventional WWTPs [9]. Clara et al. found that CBZ removal was negligible in conventional activated sludge plants, such as sequencing batch reactor (SBR) and a membrane bioreactor operated at different sludge retention times $[10,11]$. CBZ also showed resistance against removal with chlorination, coagulation, and flocculation [1] Although CBZ does not produce acute toxicity in the aquatic environment, the chronic and synergistic effects with other compounds cannot be excluded [12]. Therefore, many research works were performed to develop new strategies for CBZ removal from wastewater [13]. Several treatment methods, such as membrane separation, ozonation, and adsorption onto activated carbon showed high levels of CBZ removal $[14,15]$. However, these methods have drawbacks, such as generation of a waste stream and formation of more toxic compounds [16,17]. For example, Donner et al. analyzed the transformation products of CBZ during ultraviolet (UV) photolysis with three standard ecotoxicity assays (algae, bacteria, and crustaceans) and observed higher toxicity compared to the parent compound [18].

As an alternative to the mentioned methods, biocatalytic degradation of PhACs with enzymes may provide environmentally benign approaches that require low energy input and moderate conditions. Furthermore, the specificity of the enzymatic methods leads to minimization of the undesirable products $[13,19]$. Therefore, enzymes offer

\footnotetext{
* Corresponding author.

E-mail address: satinder.brar@ete.inrs.ca (S.K. Brar).
} 
a promising tool for selective and efficient removal of pollutants from water and wastewater streams [13,19]. Among biocatalytic systems, using white-rot fungi (WRF) attracted much attention since they can degrade recalcitrant pollutants through their ligninolytic enzymes i.e. laccase $[20,21]$, manganese peroxidase $(\mathrm{MnP})$ and lignin peroxidase (LiP) [22]. For example, Jelic et al. used Trametes versicolor to remove CBZ with an air pulsed fluidized bioreactor in continuous mode and obtained removal efficiency of $54 \%$. They also observed no toxicity in final culture broth [19]. Besides whole fungal culture, the use of crude or purified ligninolytic enzymes for removal of contaminants has also been investigated. Laccase is one of the most targeted ligninolytic enzymes for degradation of phenolic and non-phenolic contaminants due to its stability, low cost, feasible production and broad substrate specificity [23]. The capability of laccase to degrade different compounds, such as pesticides, dyes, and polycyclic aromatic hydrocarbons to less toxic by-products, made it attractive for wastewater bioremediation $[13,24]$. Recent studies on the degradation of CBZ with laccase showed poor degradation efficiency due to the presence of an electron withdrawing group such as amide in CBZ structure. This functional group caused severe electron deficiency and made CBZ less susceptible to oxidation by laccase [25]. In this case, using redox mediators, such as 2 , 2'-azino-bis (3-ethyl-benzothiazoline-6-sulfonic acid) (ABTS) and 1hydro-xybenzotriazole (HBT) can enhance the oxidizing capability of laccase toward recalcitrant compounds [24,26,27]. For example, Hata et al. observed that addition of HBT increased the degradation efficiency of CBZ by laccase from $22 \%$ to $60 \%$ [27].

Although the capability of laccase-mediator systems for degradation of pollutants has been already verified, production of pure laccase is cost-intensive laccase and challenges its commercial application. Likewise, the influence of operational parameters has not been statistically investigated to develop a reliable and efficient treatment method. In this work, fermentation of a cost-effective substrate i.e. apple pomace was used to produce laccase by Trametes versicolor. Subsequently, the effects of four parameters including enzyme concentration, mediator concentration, temperature and $\mathrm{pH}$ on the biotransformation rate of laccase for $\mathrm{CBZ}$ were studied using response surface methodology (RSM) which is an experimental approach to find the optimum conditions for a system with several variables. Finally, the CBZ biotransformation products were identified and yeast estrogenic toxicity bioassay was performed to understand the effect of biocatalytic treatment on the CBZ toxicity. To the best of our knowledge, this is the first study that investigates the performance of crude laccase-mediator for the removal of CBZ at the environmentally-related concentrations. Working at this range is of significance since the results are more reliable and it is possible to extrapolate them to real conditions.

\section{Materials and methods}

\subsection{Chemicals}

Carbamazepine (CBZ) and 2, 2'-azino-bis (3-ethylbenzothiazoline-6sulphonic acid) (ABTS) were procured from Sigma-Aldrich (Oakville, Canada) with purity of $>99 \%$. Carbamazepine (D10), as an internal standard, was purchased from CDN Isotopes (Pointe-Claire, Canada). Methanol and Tween 80 were obtained from Fisher Scientific (Ottawa, Canada). Ultrapure water was produced in the laboratory using a MilliQ/Milli-Ro Millipore system (Massachusetts, USA). The ultrapure water was used for the preparation of stock solutions and samples for degradation tests.

\subsection{Preparation of inoculum}

The fungus, Trametes versicolor (Tv) (ATCC (American Type Culture Collection) 20869) was grown aerobically in a liquid medium (Potato dextrose broth) $(2.4 \% \mathrm{w} / \mathrm{v}$ and $30 \mathrm{~mL})$ at $30 \pm 1{ }^{\circ} \mathrm{C}$ and $150 \mathrm{rpm}$ for 7 days. The inoculum was prepared by growing the fungus $(100 \mu \mathrm{L}$ from
PDB (Potato dextrose broth) media) on potato dextrose agar (PDA) plates for 9 days at $30 \pm 1{ }^{\circ} \mathrm{C}$. After incubation, the plates were stored at $4 \pm 1{ }^{\circ} \mathrm{C}$ prior to use for fermentation.

\subsection{Solid-state fermentation and enzyme extraction}

Apple pomace (Vergers Paul Jodoin Inc., Quebec, Canada) was used as a solid substrate for the production of laccase by the Tv. In brief, $40 \mathrm{~g}$ of solid substrate (78\% moisture $(\mathrm{w} / \mathrm{w})$ and $\mathrm{pH} 4.5)$, along with Tween 80 at $0.5 \% \mathrm{v} / \mathrm{w}$ in a $500 \mathrm{~mL}$ Erlenmeyer flasks were magnetically stirred (Isotemp ${ }^{\mathrm{TM}}$ Stirrer, Fisher Scientific) and autoclaved (3870 ELV, Heidolph) at $121 \pm 1{ }^{\circ} \mathrm{C}$ for $20 \mathrm{~min}$. After inoculation, the substrate was thoroughly mixed and incubated in a static incubator (Isotemp Incubator Fisher Scientific) for 14 days at $30 \pm 1{ }^{\circ} \mathrm{C}$. For extraction of laccase, one gram of fermented sample was added to $20 \mathrm{~mL}$ of $50 \mathrm{mM}$ sodium phosphate buffer ( $\mathrm{pH}$ 6.5). Then, the mixture was mixed using a shaker incubator (Multitron, Infors HT) at $150 \mathrm{rpm}$ and $35 \pm 1{ }^{\circ} \mathrm{C}$ for $1 \mathrm{~h}$ and centrifuged (Sorvall RC 5C, Dupont) for $30 \mathrm{~min}$ at $4{ }^{\circ} \mathrm{C}$ and $7000 \times g$. The collected supernatant was analyzed spectrophotometrically (Cary 300 Bio, Varian) for respective laccase activity expressed as activity per gram of dry culture (Section 2.4). The supernatant was freeze-dried at $-55^{\circ} \mathrm{C}$ and $5 \mathrm{~Pa}$ for $48 \mathrm{~h}$ and kept at $-20^{\circ} \mathrm{C}$ (Revco, Fisher Scientific) before performing the experiments.

\subsection{Enzyme assay}

Oxidation of ABTS was used to measure the laccase activity. $500 \mu \mathrm{L}$ ABTS $(1.5 \mathrm{mM})$ was mixed with $2.450 \mathrm{~mL}$ of $0.1 \mathrm{M}$ citrate-phosphate buffer ( $\mathrm{pH} 4)$ and $50 \mu \mathrm{L}$ of enzyme sample. ABTS oxidation was monitored at $45 \pm 1{ }^{\circ} \mathrm{C}$ by recording the absorbance at $420 \mathrm{~nm}$ $\left(\varepsilon_{420}=36,000 \mathrm{M}^{-1} \mathrm{~cm}^{-1}\right)$ for $10 \mathrm{~min}$ [28]. One activity unit of laccase was defined as the amount of required enzyme to oxidize $1 \mu \mathrm{mol}$ of ABTS per min under the mentioned conditions. The average of the three measurements was reported as final laccase activity.

\subsection{Experimental design and degradation efficiency}

Central composite design (CCD) and response surface methodology (RSM) was employed to study the degradation efficiency of laccase as a function of temperature $\left({ }^{\circ} \mathrm{C}\right)$, ABTS concentration $(\mu \mathrm{M})$, enzyme concentration (U/L) and $\mathrm{pH}$. The degradation efficiency for CBZ was considered as the dependent variable. Independent parameters and their corresponding levels are listed in Table 1. Design-Expert -7 software (Stat-Ease Inc., Minneapolis, USA) was used in the formation of the experimental array which resulted in 30 experiments with 6 replicates in the center. The details of designed experiments are listed in Table 2. In each experiment, exact concentration of enzyme and ABTS along with CBZ (1 ppm) were mixed in desired $\mathrm{pH}$ (total volume of $10 \mathrm{~mL}$ ). The flask was later kept at suitable respective temperature $\left(25-45^{\circ} \mathrm{C}\right)$ and $150 \mathrm{rpm}$. After $24 \mathrm{~h}$, the reaction was stopped by addition of methanol $(1: 1 \mathrm{v} / \mathrm{v}$ ratio) and the sample was analyzed.

\subsection{Kinetics of laccase-mediated CBZ degradation}

Degradation kinetics of CBZ was carried out for CBZ at an initial

Table 1

Independent parameters and their coded levels used for degradation optimization.

\begin{tabular}{lllllll}
\hline Independent factor & Units & \multicolumn{2}{l}{ Coded levels } \\
\hline Levels & & -2 & -1 & 0 & +1 & +2 \\
Temperature & ${ }^{\circ} \mathrm{C}$ & 25 & 30 & 35 & 40 & 45 \\
ABTS concentration & $\mu \mathrm{M}$ & 2 & 6 & 10 & 14 & 18 \\
$\mathrm{pH}$ & - & 4 & 5 & 6 & 7 & 8 \\
Enzyme concentration & $\mathrm{U} / \mathrm{L}$ & 20 & 40 & 60 & 80 & 100 \\
\hline
\end{tabular}


Table 2

Four-factor and five-level central composite designs for RSM and experimentally achieved degradation efficiency.

\begin{tabular}{|c|c|c|c|c|c|}
\hline No. & Temperature $\left({ }^{\circ} \mathrm{C}\right)$ & $\begin{array}{l}\text { ABTS } \\
\text { concentration } \\
(\mu \mathrm{M})\end{array}$ & $\mathrm{pH}$ & $\begin{array}{l}\text { Enzyme } \\
\text { concentration } \\
\text { (U/L) }\end{array}$ & $\begin{array}{l}\text { Degradation } \\
\text { efficiency } \\
(\%)\end{array}$ \\
\hline 1 & 30 & 6 & 5 & 40 & 68.76 \\
\hline 2 & 40 & 6 & 5 & 40 & 64.68 \\
\hline 3 & 30 & 14 & 5 & 40 & 81.58 \\
\hline 4 & 40 & 14 & 5 & 40 & 66.81 \\
\hline 5 & 30 & 6 & 7 & 40 & 63.49 \\
\hline 6 & 40 & 6 & 7 & 40 & 67.32 \\
\hline 7 & 30 & 14 & 7 & 40 & 69.68 \\
\hline 8 & 40 & 14 & 7 & 40 & 65.55 \\
\hline 9 & 30 & 6 & 5 & 80 & 71.21 \\
\hline 10 & 40 & 6 & 5 & 80 & 76.34 \\
\hline 11 & 30 & 14 & 5 & 80 & 70.65 \\
\hline 12 & 40 & 14 & 5 & 80 & 69.15 \\
\hline 13 & 30 & 6 & 7 & 80 & 46.78 \\
\hline 14 & 40 & 6 & 7 & 80 & 55.52 \\
\hline 15 & 30 & 14 & 7 & 20 & 70.04 \\
\hline 16 & 40 & 14 & 7 & 80 & 58.76 \\
\hline 17 & 25 & 10 & 6 & 60 & 68.93 \\
\hline 18 & 45 & 10 & 6 & 60 & 73.34 \\
\hline 19 & 35 & 2 & 6 & 60 & 72.71 \\
\hline 20 & 35 & 18 & 6 & 60 & 94.75 \\
\hline 21 & 35 & 10 & 4 & 60 & 76.23 \\
\hline 22 & 35 & 10 & 8 & 60 & 65.35 \\
\hline 23 & 35 & 10 & 6 & 20 & 77.28 \\
\hline 24 & 35 & 10 & 6 & 100 & 79.59 \\
\hline $25(\mathrm{C})$ & 35 & 10 & 6 & 60 & 86.61 \\
\hline $26(\mathrm{C})$ & 35 & 10 & 6 & 60 & 86.00 \\
\hline $27(\mathrm{C})$ & 35 & 10 & 6 & 60 & 86.61 \\
\hline $28(\mathrm{C})$ & 35 & 10 & 6 & 60 & 86.00 \\
\hline 29 (C) & 35 & 10 & 6 & 60 & 86.61 \\
\hline $30(\mathrm{C})$ & 35 & 10 & 6 & 60 & 86.00 \\
\hline
\end{tabular}

concentration of $1000 \mu \mathrm{g} / \mathrm{L}$ and enzyme activity of $60 \mathrm{U} / \mathrm{L}$ for $24 \mathrm{~h}$. Sampling was performed at different time intervals $(0.5,1.5,2,3,4,6$, $7,8,16$ and 24). Also, different initial concentrations of CBZ $(2 \mu \mathrm{g} / \mathrm{L}$, $10 \mu \mathrm{g} / \mathrm{L}, 20 \mu \mathrm{g} / \mathrm{L}, 100 \mu \mathrm{g} / \mathrm{L}, 200 \mu \mathrm{g} / \mathrm{L}, 1000 \mu \mathrm{g} / \mathrm{L}$ and $2000 \mu \mathrm{g} / \mathrm{L})$ was used against $60 \mathrm{U} / \mathrm{L}$ of laccase in constant reaction time of $12 \mathrm{~h}$ to determine the parameters of Michaelis-Menten kinetics. The parameters in Michaelis-Menten kinetics were determined by measuring the initial degradation rate of CBZ at different CBZ concentrations (Eq. (1)) [29].

$V=\frac{V_{m}[S]}{K_{M}+[S]}$

In this equation, $\mathrm{V}\left(\mu \mathrm{g} \mathrm{L} \mathrm{L}^{-1} / \mathrm{h}\right)$ is the reaction rate, $\mathrm{V}_{\mathrm{m}}\left(\mu \mathrm{g} \mathrm{L}^{-1} / \mathrm{h}\right)$ is the maximum reaction rate, $[\mathrm{S}]$ is the substrate concentration, and $\mathrm{K}_{\mathrm{M}}$ is a constant. $\mathrm{K}_{\mathrm{m}}$ and $\mathrm{V}_{\max }$ values are determined by fitting the data into the Lineweaver-Burk plot, which resulted from Michaelis-Menten plot conversion.

\subsection{Quantification of $C B Z$}

Quantification of CBZ was performed on a liquid chromatography quadrupole (LCQ) Duo ion trap tandem mass spectrometer (Thermo Finnigan, USA) coupled with a Laser Diode Thermal Desorption (LDTD) (Phytronix technologies, Canada). The identified daughter ions for CBZ were 194 and $192 \mathrm{Da}$. The calibration curve of CBZ concentration comprised six standard solutions and the $\mathrm{R}^{2}$ was greater than 0.99 . The details of quantification process were described elsewhere [30]. All the experiments were performed in duplicates and the average results were reported.

\subsection{Data analysis}

The results obtained from experiment based on CCD were analyzed with RSM and fitted to a second-order polynomial model. The equation
(Eq. (2)) mentioned below was employed in the RSM analysis to correlate the dependent and independent variables.

$\mathrm{Y}=\beta_{0}+\sum_{i=1} \beta_{i} X_{i}+\Sigma \beta_{i i} X_{i}^{2}+\sum_{i=1} \sum_{j=i+1} \beta_{i j} X_{i} X_{j}$

In this equation $Y, \beta_{0}, X_{i}\left(\right.$ or $\left.X_{j}\right) . \beta_{i}, \beta_{i i}$, and $\beta_{i j}$ are the predicted responses for the dependent variable, second-order constant, independent variable, the coefficient of linear regression, the coefficient of quadratic regression and coefficient of interactions regression between two independent variables, respectively.

The calculated degradation efficiency (\%) for each run was chosen as the response (dependent) variable. The relationship between the independent parameters and the response variable was determined by design matrix evaluation, by taking the response surface quadratic model for interactions into consideration. The significance of the regression was tested and models with a $p$-value higher than 0.05 were not considered. The best fit for polynomial models was evaluated from adjusted coefficient of determination ( $\mathrm{R}^{2}$ values) and final equation in terms of factors and lack of fit test (LOF) was obtained by analysis of variance (ANOVA).

\subsection{By-product identification}

Accurate mass of $\mathrm{CBZ}$ and its biotransformation products under the optimum conditions were measured by LDTD-mass spectrometry (MS) and LDTD-MS-MS in the $m / z$ range of $10-1000$. About $4 \mu \mathrm{L}$ of each sample was placed into the 96 -well plates and dried at $35^{\circ} \mathrm{C}$. The sample was desorbed by laser power and guided into Atmospheric pressure chemical ionization (APCI) module to ionize all the compounds. Later, the ionized molecules were guided into the mass spectrometer and their $m / z$ ratio was scanned. After selecting the most probable $m / z$ for by-products, another experiment was performed with LDTD-MS-MS to scan the daughter ions of by-products in the second mass spectrophotometer.

\subsection{Yeast estrogen screen (YES) assay}

The YES assay described by Routledge and Sumpter was employed to measure the estrogenic activity of CBZ and its degradation by-products [31]. The procedure for the determination of the total estrogenic activity was carried out by serial dilution of CBZ, its by-products and $17 \beta$-estradiol (as standard) in ethanol across 12 wells in a 96-well plate (Costar Brand, NY, and the USA). In the first row of the plate, $10 \mu \mathrm{L}$ of ethanol was placed in each well as blank. In the second and third rows, $10 \mu \mathrm{L} 17 \beta$-estradiol with different concentrations $(0,0.5 \mathrm{ng} / \mathrm{L}, 5 \mathrm{ng} / \mathrm{L}$, ..., $5 \mathrm{mg} / \mathrm{L}, 50 \mathrm{mg} / \mathrm{L}$ ) was placed in duplicate. In the fourth-row, CBZ sample at $1 \mathrm{mg} / \mathrm{L}(4 \mu \mathrm{M})$ and its degradation by-products (with and without ABTS) were placed in quadruplicate. Later, the plate was conditioned under laminar flow for complete drying of the samples. $200 \mu \mathrm{L}$ of the seeded assay medium containing chlorophenol red- $\beta$-Dgalactopyranoside (CPRG) and the yeast (hER-transfected recombinant yeast) were added to the samples. The sealed plate with parafilm was incubated for 3 days at $32 \pm 1{ }^{\circ} \mathrm{C}$. The color development of the samples was checked periodically for qualitative assessment of toxicity.

\section{Result and discussion}

\subsection{Production of crude laccase}

TV is known as an excellent producer of laccase at industrial scale [32]. To have a sufficient amount of crude laccase in this study, laccase was biosynthesized by fermentation of apple pomace. Fig. 1 depicts the profile of laccase production during the fermentation period. The results showed that during the first 5 days of fermentation, no laccase activity was detected in the cultures. After the 6th day, laccase production started and reached its maximum on the 13th day (1800 U/L), 


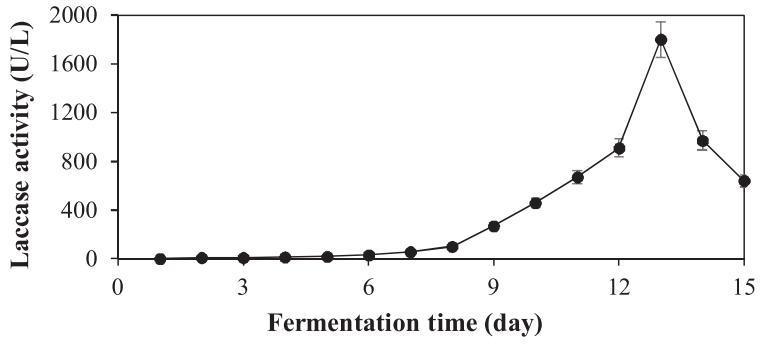

Fig. 1. Production of laccase during fermentation of T. versicolor (Y-axis is the laccase activity in crude extract. The error bars represent standard deviation of two replicates).

and then decreased. No MnP or LiP activity was found during the fermentation, which can be due to the properties of strain, substrate and the fermentation conditions [32].

\subsection{Fitting the degradation model}

The effect of different parameters and their interactions on the biotransformation of CBZ was investigated. The RSM design considered central points (0), low $(-)$ and high $(+)$ levels for the parameters (Table 1). The values of parameters for all designed experiments and the obtained results are summarized in Table 2. The obtained data were analyzed to determine the coefficients of the quadratic model. The mathematical expression of the relationship of CBZ biotransformation with variables, $\mathrm{A}-\mathrm{D}$ (temperature, ABTS concentration, $\mathrm{pH}$ and enzyme concentration, respectively) are given below in Eq. (3) in terms of coded factors:

$\mathrm{Y}=+86.10-0.38 \mathrm{~A}+3.43 \mathrm{~B}-3.91 \mathrm{C}-1.03 \mathrm{D}-2.83 \mathrm{AB}+0.77$

$\mathrm{AC}+1.27 \mathrm{AD}+1.48 \mathrm{BC}-0.04 \mathrm{BD}-2.53 \mathrm{CD}-5.30 \mathrm{~A}^{2}-2.16$

$\mathrm{B}^{2}-5.39 \mathrm{C}^{2}-3.48 \mathrm{D}^{2}$

The results of ANOVA for the biotransformation of CBZ have been summarized in Table 3 . The probability $(P)$ value and the R-squared of the whole quadratic model were 0.0126 and 0.759 . Therefore, the regression of the quadratic equation for CBZ biotransformation was significant and applicable for practical applications. According to Table 3, the $P$ values of quadratic and linear coefficients are less than 0.05 which means they are generally significant through the model. Moreover, the $P$ value for interaction coefficients was 0.528 which indicates the insignificance of interactions within this model. This observation may be related to the fact that some parameters have a negligible effect on each other for the biotransformation of CBZ. The observed CBZ removal efficiency varied between $47 \%\left(30^{\circ} \mathrm{C}, 6 \mu \mathrm{M}\right.$ ABTS, pH 7 and $80 \mathrm{U} / \mathrm{L}$ enzyme) and $95 \%\left(35^{\circ} \mathrm{C}, 18 \mu \mathrm{M} \mathrm{ABTS}, \mathrm{pH} 6,60 \mathrm{U} / \mathrm{L}\right.$ enzyme).

Based on F-value, the linear effects of ABTS concentration and $\mathrm{pH}$ and also the quadratic effect of temperature, $\mathrm{pH}$ and enzyme concentration were the most significant contributors to the efficiency of CBZ degradation. The RSM procedure predicted a convex shape for response surfaces, which means there is a unique optimum point for biotransformation efficiency. The details of parameters' role in

Table 3

ANOVA of the regression parameters of the predicted response surface model for degradation of CBZ.

\begin{tabular}{llllll}
\hline Regression & $\begin{array}{l}\text { Degrees of } \\
\text { freedom }\end{array}$ & $\begin{array}{l}\text { Sum of } \\
\text { squares }\end{array}$ & $\begin{array}{l}\text { Mean } \\
\text { square }\end{array}$ & F-value & Pr $>$ F \\
\hline Linear & 4 & 677.85 & 169.46 & 3.23 & 0.0156 \\
Quadratic & 4 & 2027.36 & 506.84 & 9.65 & 0.0001 \\
Interaction & 6 & 300.84 & 50.14 & 0.96 & 0.5280 \\
Residual error & 15 & 787.72 & 52.51 & & \\
Lack of fit & 10 & 787.42 & 78.74 & 1281.25 & $<0.0001$ \\
Pure error & 5 & 0.31 & 0.061 & & \\
Total model & 14 & 2490.80 & 177.91 & 3.39 & 0.0126 \\
\hline
\end{tabular}

biotransformation are discussed in the following sections.

\subsection{Effect of $p H$ and temperature on $C B Z$ degradation}

Fig. 2 presents the degradation efficiency of CBZ by the laccaseABTS system at different $\mathrm{pH}$ and temperatures. It is evident that $\mathrm{pH}$ has both quadratic and linear effects on CBZ biotransformation within the studied range of 4-8. In pH range of 5.5-6, CBZ was almost completely degraded by the laccase-ABTS system ( $>95 \%)$. However, by increasing the $\mathrm{pH}$ to 7 , the degradation efficiency significantly ( $p$-value $<0.02$ ) decreased to $62 \%$. This behavior is in accordance with the reduction of laccase activity at higher $\mathrm{pH}$ values compared to the acidic $\mathrm{pH}$ range. It has been already proven that the highest oxidation level by laccase was obtained at $\mathrm{pH}$ range of 4-6 [24]. The reduction of laccase activity reduced the rate of generation of mediator radical and slowed down CBZ oxidation. Also, for other ligninolytic enzymes e.g. LiP, the activity decreased at $\mathrm{pH}$ values higher than 4.5 due to inactivation of the enzyme [33]. Cantarella et al. also reported a drastic reduction in laccase activity when $\mathrm{pH}$ was over 7 [34]. Huerta-Fontela et al. reported that CBZ degradation with chlorination was enhanced at higher chlorine concentrations. They concluded that $\mathrm{CBZ}$ removal depended on $\mathrm{pH}$ so that at higher $\mathrm{pH}$ values ( $>7$ ), the $\mathrm{CBZ}$ removal was lower at lower $\mathrm{pH}$ [1]. The enzymes were mainly stabilized by weak interactions, such as Van der Waals and hydrogen bonds. The latter is largely influenced by the medium $\mathrm{pH}$ and therefore increasing or decreasing the $\mathrm{pH}$ beyond certain range reduced the stability and activity of the enzyme [35].

Complete removal of $\mathrm{CBZ}$ was observed at $35^{\circ} \mathrm{C}$ while the degradation efficiency was $69 \%$ and $73 \%$ at $25^{\circ} \mathrm{C}$ and $45^{\circ} \mathrm{C}$, respectively. Decreased degradation efficiency at a lower temperature $\left(25^{\circ} \mathrm{C}\right)$ was due to the lowered activation energy of the reaction. On the other hand, decreasing the efficiency at higher temperatures was due to inactivation of laccase [34]. Temperature played an important role in the rate of biological reactions. However, above a certain temperature $\left(40{ }^{\circ} \mathrm{C}\right)$, the rate of biological reactions experienced a decrease due to the denaturation of related enzymes [35]. Furthermore, the analysis of the surface plot for the effect of $\mathrm{pH}$ and temperature revealed that the interaction effect of two parameters was negligible.

\subsection{Effect of enzyme and mediator concentration}

The effect of enzyme and ABTS concentration on CBZ biotransformation are depicted in Fig. 3. According to Fig. 3, increasing the enzyme concentration from 40 to $60 \mathrm{U} / \mathrm{L}$, increased the biotransformation efficiency (from around $70 \%$ to $95 \%$ ) but a further increase to $80 \mathrm{U} / \mathrm{L}$ decreased the biotransformation efficiency to the same level as observed for $40 \mathrm{U} / \mathrm{L}$. It showed that the enzyme concentration had only a quadratic effect on biotransformation. Higher laccase activity led to a rapid generation of ABTS radicals, which attacked CBZ and caused efficient transformation of CBZ. Similar results were observed in the research work of Tran et al., who reported that while increasing the laccase activity from $2000 \mathrm{U} / \mathrm{L}$ to $6000 \mathrm{U} / \mathrm{L}$, the degradation efficiency increased 4.3 folds [32]. Further addition of enzyme to the solution increase the collisions and interactions among enzyme macromolecules and they can block each other's active sites. Therefore, at higher concentrations of enzyme, compared to the optimum level, the degradation efficiency was reduced.

On the other hand, increasing the ABTS concentration in the whole studied range $(6-14 \mu \mathrm{M})$ enhanced the biotransformation efficiency, which is derived from the linearity of the effect. The CBZ degradation efficiency was improved from $47 \%$ to $95 \%$ by increasing the ABTS concentration from $6 \mu \mathrm{M}$ to $14 \mu \mathrm{M}$. Ji et al. observed that less than $5 \%$ of CBZ was removed by free laccase in $96 \mathrm{~h}$ while the addition of a mediator ( $p$-coumaric acid) increased the degradation efficiency to more than $60 \%$ [13]. Similarly, Hata et al. observed increase in the removal efficiency of CBZ from 39\% to $60 \%$ after addition of HBT as redox mediator [27]. 


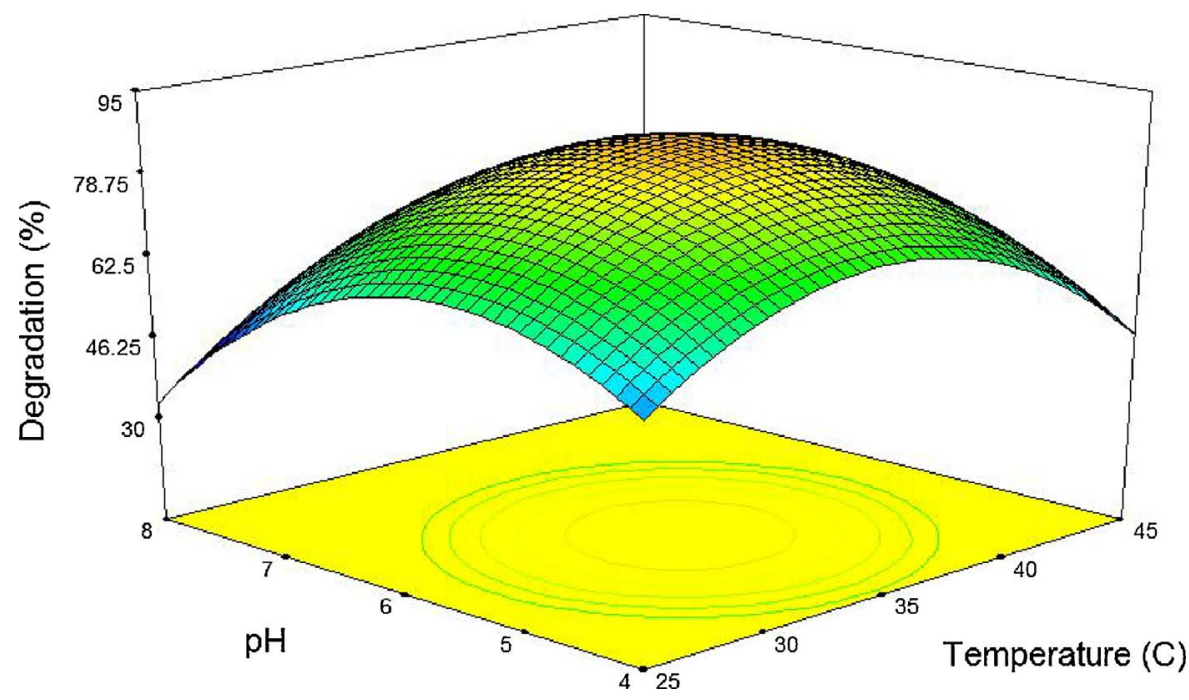

Fig. 2. Influence of $\mathrm{pH}$ and temperature on the degradation of carbamazepine by laccase-ABTS system.

The presence of a mediator allows the enzyme to overcome a kinetic barrier [36]. Mediators can stabilize the enzyme through binding to its active site or another suitable region on the protein structure of enzyme [37]. The capability of ABTS for degradation of CBZ was evaluated in another experiment through monitoring the removal efficiency of CBZ by laccase over $24 \mathrm{~h}$ treatment in presence and absence of ABTS. The results of this test were depicted in Fig. 4. Accordingly, CBZ was not a highly reactive substrate for laccase and less than 30\% of CBZ was degraded by free laccase after $24 \mathrm{~h}$. In comparison, in the presence of ABTS, the degradation efficiency of CBZ was improved to more than $82 \%$ after $24 \mathrm{~h}$. In laccase-mediator systems, laccase oxidize the mediator to form reactive radicals (ABTS ${ }^{+}$with $0.61 \mathrm{~V}$ or perhaps $\mathrm{ABTS}^{++} 1.1 \mathrm{~V}$ redox potential), which can oxidize recalcitrant compounds through one electron transfer mechanism [13,26,34]. Free radicals can also react with compounds through radical-radical reactions and hydrogen abstraction [24]. The general theory is that the mediator carries out the oxidation of the substrate in a catalytic cycle by turning over between its natural and oxidised $\left(\mathrm{Med}_{\mathrm{ox}}\right)$ states [34]. Also, the intervention of by-products of the $\mathrm{Med}_{\mathrm{ox}}$ species is possible. The nonphenolic substrate can be oxidised by reacting with mediator's byproducts $[38,39]$.

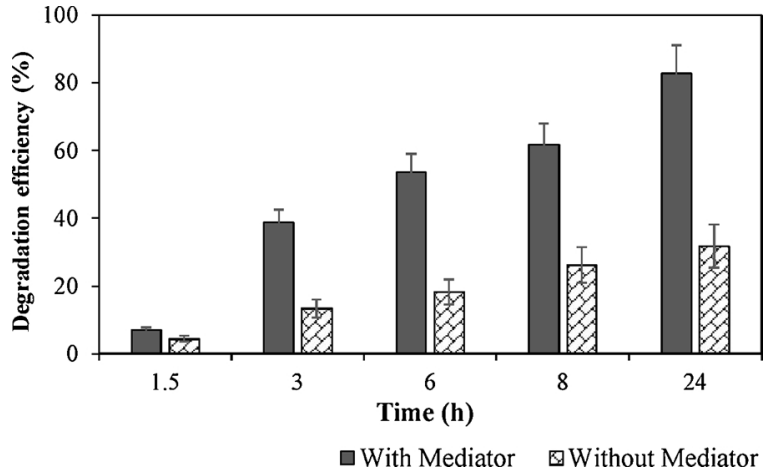

Fig. 4. Carbamazepine degradation during reaction with laccase without mediator (White) and with mediator (Gray) $(1 \mathrm{mg} / \mathrm{L}(4 \mu \mathrm{M})$ carbamazepine, $18 \mu \mathrm{M}$ ABTS, pH 6 , $60 \mathrm{U} / \mathrm{mL}$ initial laccase activity).

\subsection{Kinetics of degradation of $C B Z$}

Analysis of data can lead to estimation of the dependent variable within the range of parameters and also can suggest several optimum points with maximum degradation efficiency. According to the results, by setting temperature, $\mathrm{pH}$, enzyme concentration and ABTS concentration to $35^{\circ} \mathrm{C}, 6,60 \mathrm{U} / \mathrm{L}$ and $18 \mu \mathrm{M}$, respectively can increase the

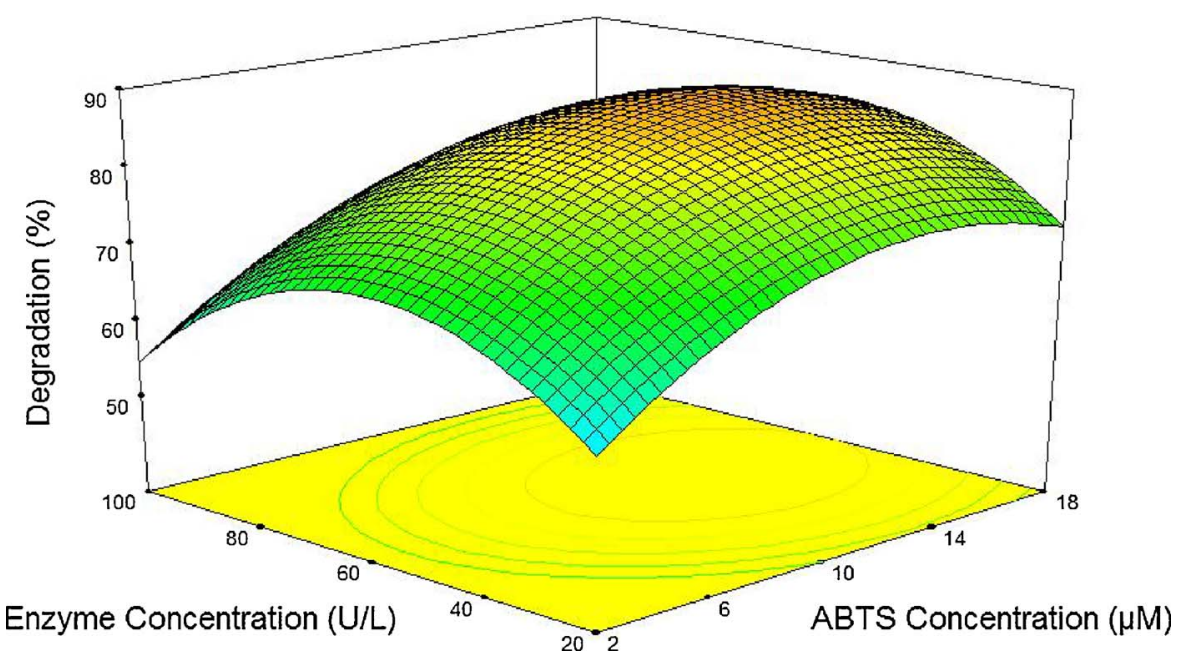

Fig. 3. Response surface plot showing the effect of enzyme and ABTS concentration on the degradation of carbamazepine (\%). 


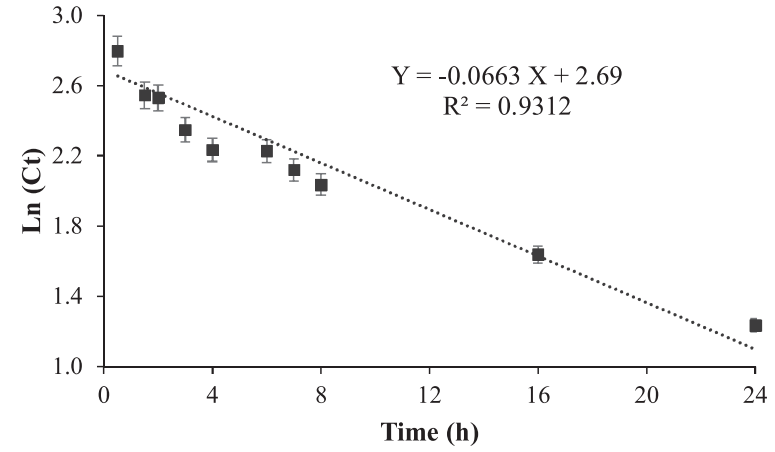

Fig. 5. Plot for first-order kinetics of carbamazepine biotransformation with laccase and ABTS $\left(\mathrm{C}_{0}=1 \mathrm{mg} / \mathrm{L}, 35^{\circ} \mathrm{C}\right.$, time $\left.=24 \mathrm{~h}, \mathrm{pH}=6\right)$.

degradation efficiency of CBZ by laccase-ABTS system to more than 95\%. These parameters' levels along with CBZ concentration of $1000 \mathrm{ppb}$ were selected for kinetic study. The time evolution trends of concentration of CBZ in the optimized conditions is illustrated in Fig. 5. As predicted by the software, CBZ was almost completely degraded (95\%) by laccase-ABTS system after $24 \mathrm{~h}$ of incubation. The CBZ degradation efficiency was $60 \%$ during the first $8 \mathrm{~h}$. Enzymatic processes generally follow Michaelis-Menten kinetic model according to which the degradation rate is of first order at very low substrate concentrations. Therefore, due to very low concentrations of micropollutants $(\mu \mathrm{M}$ level) in environmental compartment, degradation of these compounds can be fitted by a first order reaction rate [40]. Assuming the first-order kinetics for degradation, the constants were determined by plotting logarithmic concentrations against time (Fig. 5). The kinetic constant, $K$, was determined to be $0.07\left(\mathrm{~h}^{-1}\right)\left(R^{2}=0.93\right)$. At environmentally relevant concentrations, the rate of reaction is significantly lower than high concentrations. For example, in a research by Jelic et al., white-rot fungus TV, eliminated $94 \%$ of CBZ at initial concentration of $9 \mathrm{mg} / \mathrm{L}$ after 6 days while at initial concentration of $50 \mu \mathrm{g} / \mathrm{L}, 61 \%$ of CBZ was degraded in 7 days [19]. Furthermore, Lineweaver-Burk model was used to determine the Michaelis-Menten parameters i.e. $\mathrm{K}_{\mathrm{m}}$ and $\mathrm{V}_{\max }$. The plot was fitted very well with an $\mathrm{R}^{2}$ of 0.9996 and accordingly, $\mathrm{V}_{\text {max }}$ and $\mathrm{K}_{\mathrm{m}}$ were found to be $29.85 \mu \mathrm{g} \mathrm{L}{ }^{-1} \mathrm{~h}^{-1}$ and $498.60 \mu \mathrm{g} / \mathrm{L}$ (plot not shown). The results of Lineweaver-Burk model are in excellent agreement with the first order model as the ratio of $V_{\max }$ to $\mathrm{K}_{\mathrm{m}}$ was calculated to be around $0.06 \mathrm{~h}^{-1}$.

\subsection{Metabolites identification of CBZ biotransformation}

To identify the CBZ biotransformation products, a full-scan chromatogram for sample taken after $24 \mathrm{~h}$ of treatment by the laccase-ABTS system at optimal parameters was recorded over $m / z$ range of 70-300. The protonated molecule of parent compound CBZ appeared at $m / z$ of 237.10. Several more peaks were observed at $\mathrm{m} / \mathrm{z} 271.10$ and 253.10 which are attributed to 10,11-dihydro-10,11-dihydroxy-CBZ (DiOHCBZ), 10,11-dihydro-10,11-epoxy-CBZ (EP-CBZ). EP-CBZ has been already reported as the major by-product of $\mathrm{CBZ}$ by oxidation with fungal whole cell and laccase $[13,41]$. The appearance of two product ions at $\mathrm{m} / \mathrm{z}$ of 236 and 210 in MS-MS spectrum (data not shown) of EP-CBZ ( $\mathrm{m} /$ $z: 253, \mathrm{C}_{15} \mathrm{H}_{13} \mathrm{~N}_{2} \mathrm{O}_{2}$ ) is similar to the $\mathrm{CBZ}$ spectrum which undergoes loss of ammonia (17 Da) or HNCO (43 Da), respectively. Likewise, DiOH-CBZ $\left(m / z: 271.1, \mathrm{C}_{15} \mathrm{H}_{15} \mathrm{~N}_{2} \mathrm{O}_{3}\right)$ resulted in three product ions at $\mathrm{m} / z 253,236$ and 210 through loss of a water molecule followed by the abstraction of ammonia or HNCO, respectively (See Fig. 6) . According to Bahlmann et al., the level of concern estimated for EP-CBZ was similar to CBZ, while higher levels of concern estimated for DiOHCBZwere higher than the parent compound [6].

\subsection{Estrogenic activity of CBZ by-products}

The YES test is a method in which the human estrogen receptor (hER) should be expressed in yeast so that in an estrogen-dependent manner, it can activate the transcription of a promoter carrying estrogen-responsive sequences [31]. The reproducibility and sensitivity of this assay was assessed by comparing the response of the yeast to $17 \beta$ estradiol with responses for different samples spiked with CBZ. The change in color due to addition of $17 \beta$-estradiol and different samples is presented in Fig. 7. Accordingly, the estrogenicity for samples containing $17 \beta$-estradiol, as the color turned red after 3 day of incubation. However, the samples with CBZ or its by-products did not show any changes in color. The results showed that CBZ (at $1 \mathrm{mg} / \mathrm{L}$ or $4 \mu \mathrm{M}$ ) and its by-products from treatment with laccase-ABTS system has no

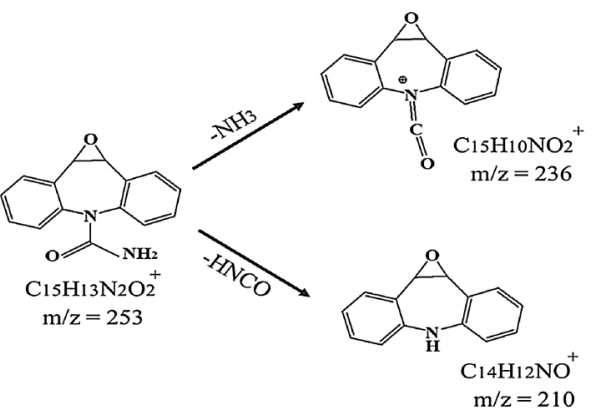<smiles>NC(=O)N1c2ccccc2C(O)C(O)c2ccccc21</smiles>

$\mathrm{C}_{15} \mathrm{H}_{15} \mathrm{~N}_{2} \mathrm{O}_{3}^{+}$

$\mathrm{m} / \mathrm{z}=271$

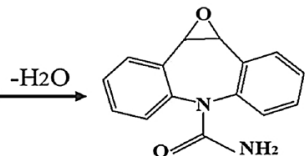

$\mathrm{C}_{15} \mathrm{H}_{13} \mathrm{~N}_{2} \mathrm{O}_{2}^{+}$ $\mathrm{m} / \mathrm{z}=253$

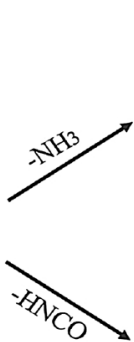

HO

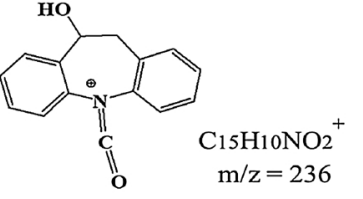<smiles>OC1CNc2ccccc2C1</smiles>

Fig. 6. Two main by-products of carbamazepine biotransformation and their related daughter ions in tandem mass spectroscopy. 


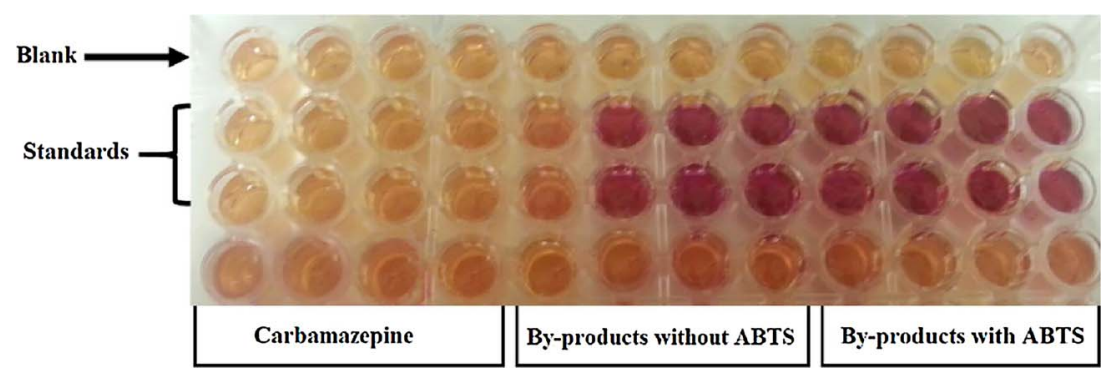

Fig. 7. Yeast estrogenic activity assay of blank, E2 (17- $\beta$ estradiol) and samples with carbamazepine.

estrogenic activity. Therefore, this enzymatic treatment may be considered as a safe disposal strategy for wastewater disposal. Ji et al. employed the growth inhibition of algae using as a viability indicator for CBZ toxicity. They observed that $24 \mathrm{~h}$ incubation in CBZ solution $(0.4 \mu \mathrm{M})$, resulted in $95 \%$ mortality of $C$. marina cell viability, while the effluent of a laccase-mediator system (with $20 \mu \mathrm{M}$ initial CBZ) had no effect on viability [13]. In contrast, Jelic et al., used Microtox test (Vibrio fischeri luminescence) to assess the toxicity of the treated $\mathrm{CBZ}$ with fungus, TV. According to their results, CBZ $(200 \mu \mathrm{g} / \mathrm{L})$ showed a 15 min EC50 of $95 \%$ while the effluent of continuous reactor showed a 15 min EC50 of 77\% which meant that the by-products were more toxic than the parent compound [19]. Comparing the results in this research with the results of other researchers $[13,19]$ indicates that the presence of mediator helped to remove the estrogenicity of CBZ by facilitating the production of less estrogenic compounds.

\section{Conclusion}

Crude laccase was produced by growing Trametes versicolor and employed for degradation of CBZ in the absence and presence of the enzyme mediators, ABTS. The impacts of operational parameters along with their interactions on biotransformation of $\mathrm{CBZ}$ were investigated using central composite design of experiments and response surface methodology. The ANOVA results indicated that the linear effects of ABTS concentration and $\mathrm{pH}$ and also the quadratic effect of temperature, $\mathrm{pH}$ and enzyme concentration were significant contributors to the efficiency of CBZ degradation. The optimization results showed that at $35^{\circ} \mathrm{C}, \mathrm{pH} 6,60 \mathrm{U} / \mathrm{L}$ of laccase concentration and $18 \mu \mathrm{M}$ of ABTS concentration the degradation efficiency reached to $95 \%$ within $24 \mathrm{~h}$. 10,11-Dihydro-10,11-dihydroxy-CBZ and 10,11-dihydro-10,11-epoxyCBZ were identified as the major transformation products of CBZ degradation. The estrogenicity tests determined by yeast estrogenic activity assay revealed that the applied degradation treatment using laccase (with and without ABTS) had no estrogenicity effect. The data presented suggested that the laccase-ABTS system has potential for the removal of $\mathrm{CBZ}$ in aqueous media.

\section{Acknowledgements}

The authors are sincerely thankful to the Natural Sciences and Engineering Research Council of Canada (Discovery Grant 355254 and Strategic Grants), and Ministère des Relations Internationales du Québec (122523) (coopération Québec-Catalanya 2012-2014) for financial support. INRS-ETE is thanked for providing Mr. Mehrdad Taheran "Bourse d'excellence" scholarship for his Ph.D. studies. The views or opinions expressed in this article are those of the authors.

\section{References}

[1] M. Huerta-Fontela, M.T. Galceran, F. Ventura, Occurrence and removal of pharmaceuticals and hormones through drinking water treatment, Water Res. 45 (3) (2011) 1432-1442.

[2] A. Jelic, M. Gros, A. Ginebreda, R. Cespedes-Sánchez, F. Ventura, M. Petrovic, D. Barcelo, Occurrence partition and removal of pharmaceuticals in sewage water and sludge during wastewater treatment, Water Res. 45 (3) (2011) 1165-1176.

[3] B. Kasprzyk-Hordern, R.M. Dinsdale, A.J. Guwy, The removal of pharmaceuticals personal care products, endocrine disruptors and illicit drugs during wastewater treatment and its impact on the quality of receiving waters, Water Res. 43 (2) (2009) 363-380.

[4] T. Malchi, Y. Maor, G. Tadmor, M. Shenker, B. Chefetz, Irrigation of root vegetables with treated wastewater: evaluating uptake of pharmaceuticals and the associated human health risks, Environ. Sci. Technol. 48 (16) (2014) 9325-9333.

[5] B.T. Ferrari, N. Paxéus, R.L. Giudice, A. Pollio, J. Garric, Ecotoxicological impact of pharmaceuticals found in treated wastewaters: study of carbamazepine, clofibric acid, and diclofenac, Ecotoxicol. Environ. Saf. 55 (3) (2003) 359-370.

[6] A. Bahlmann, W. Brack, R.J. Schneider, M. Krauss, Carbamazepine and its metabolites in wastewater: analytical pitfalls and occurrence in Germany and Portugal, Water Res. 57 (2014) 104-114.

[7] C. Tixier, H.P. Singer, S. Oellers, S.R. Müller, Occurrence and fate of carbamazepine, clofibric acid, diclofenac, ibuprofen, ketoprofen, and naproxen in surface waters, Environ. Sci. Technol. 37 (6) (2003) 1061-1068.

[8] P. Verlicchi, M. Al Aukidy, E. Zambello, Occurrence of pharmaceutical compounds in urban wastewater: removal, mass load and environmental risk after a secondary treatment-a review, Sci. Total Environ. 429 (2012) 123-155.

[9] J. Radjenović, M. Petrović, D. Barceló, Fate and distribution of pharmaceuticals in wastewater and sewage sludge of the conventional activated sludge (CAS) and advanced membrane bioreactor (MBR) treatment, Water Res. 43 (3) (2009) $831-841$.

[10] M. Clara, B. Strenn, O. Gans, E. Martinez, N. Kreuzinger, H. Kroiss, Removal of selected pharmaceuticals fragrances and endocrine disrupting compounds in a membrane bioreactor and conventional wastewater treatment plants, Water Res. 39 (19) (2005) 4797-4807.

[11] M. Clara, B. Strenn, N. Kreuzinger, Carbamazepine as a possible anthropogenic marker in the aquatic environment: investigations on the behaviour of Carbamazepine in wastewater treatment and during groundwater infiltration, Water Res. 38 (4) (2004) 947-954.

[12] A. Jos, G. Repetto, J.C. Rios, M.J. Hazen, M.L. Molero, A. del Peso, M. Salguero, P. Fernández-Freire, J.M. Pérez-Martín, A. Cameán, Ecotoxicological evaluation of carbamazepine using six different model systems with eighteen endpoints, Toxicol. In Vitro 17 (5-6) (2003) 525-532.

[13] C. Ji, J. Hou, K. Wang, Y. Zhang, V. Chen, Biocatalytic degradation of carbamazepine with immobilized laccase-mediator membrane hybrid reactor, J. Membr. Sci. 502 (2016) 11-20.

[14] K. Ikehata, N. Jodeiri Naghashkar, M. Gamal El-Din, Degradation of aqueous pharmaceuticals by ozonation and advanced oxidation processes: a review, Ozone: Sci. Eng. 28 (6) (2006) 353-414.

[15] G. Laera, M.N. Chong, B. Jin, A. Lopez, An integrated MBR-TiO2 photocatalysis process for the removal of Carbamazepine from simulated pharmaceutical industrial effluent, Bioresour. Technol. 102 (13) (2011) 7012-7015.

[16] J. Radjenović, M. Petrović, F. Ventura, D. Barceló, Rejection of pharmaceuticals in nanofiltration and reverse osmosis membrane drinking water treatment, Water Res. 42 (14) (2008) 3601-3610.

[17] P. Westerhoff, H. Moon, D. Minakata, J. Crittenden, Oxidation of organics in retentates from reverse osmosis wastewater reuse facilities, Water Res. 43 (16) (2009) 3992-3998.

[18] E. Donner, T. Kosjek, S. Qualmann, K.O. Kusk, E. Heath, D.M. Revitt, A. Ledin, H.R. Andersen, Ecotoxicity of carbamazepine and its UV photolysis transformation products, Sci. Total Environ. 443 (2013) 870-876.

[19] A. Jelic, C. Cruz-Morató, E. Marco-Urrea, M. Sarrà, S. Perez, T. Vicent, M. Petrović, D. Barcelo, Degradation of carbamazepine by Trametes versicolor in an air pulsed fluidized bed bioreactor and identification of intermediates, Water Res. 46 (4) (2012) 955-964.

[20] L. Shi, H. Yu, T. Dong, W. Kong, M. Ke, F. Ma, X. Zhang, Biochemical and molecular characterization of a novel laccase from selective lignin-degrading white-rot fungus Echinodontium taxodii 2538, Process Biochem. 49 (7) (2014) 1097-1106.

[21] F. Bettin, L.O. da Rosa, O. Montanari, R. Calloni, T.A. Gaio, E. Malvessi, M.M. da Silveira, A.J.P. Dillon, Growth kinetics, production, and characterization of extracellular laccases from Pleurotus sajor-caju PS-2001, Process Biochem. 46 (3) (2011) 758-764.

[22] W. Kong, H. Chen, S. Lyu, F. Ma, H. Yu, X. Zhang, Characterization of a novel manganese peroxidase from white-rot fungus Echinodontium taxodii 2538, and its use for the degradation of lignin-related compounds, Process Biochem. 51 (11) (2016) 1776-1783. 
[23] J.-A. Majeau, S.K. Brar, R.D. Tyagi, Laccases for removal of recalcitrant and emerging pollutants, Bioresour. Technol. 101 (7) (2010) 2331-2350.

[24] H.A. Garcia, C.M. Hoffman, K.A. Kinney, D.F. Lawler, Laccase-catalyzed oxidation of oxybenzone in municipal wastewater primary effluent, Water Res. 45 (5) (2011) 1921-1932.

[25] S. Yang, F.I. Hai, L.D. Nghiem, W.E. Price, F. Roddick, M.T. Moreira, S.F. Magram, Understanding the factors controlling the removal of trace organic contaminants by white-rot fungi and their lignin modifying enzymes: a critical review, Bioresour. Technol. 141 (2013) 97-108.

[26] A.I. Cañas, S. Camarero, Laccases and their natural mediators: biotechnological tools for sustainable eco-friendly processes, Biotechnol. Adv. 28 (6) (2010) 694-705.

[27] T. Hata, H. Shintate, S. Kawai, H. Okamura, T. Nishida, Elimination of carbamazepine by repeated treatment with laccase in the presence of 1 -hydroxybenzotriazole, J. Hazard. Mater. 181 (1-3) (2010) 1175-1178.

[28] F. Gassara, S.K. Brar, R. Tyagi, R.P. John, M. Verma, J. Valero, Parameter optimization for production of ligninolytic enzymes using agro-industrial wastes by response surface method, Biotechnol. Bioprocess Eng. 16 (2) (2011) 343.

[29] K.A. Johnson, R.S. Goody, The original Michaelis constant: translation of the 1913 Michaelis-Menten paper, Biochemistry 50 (39) (2011) 8264-8269.

[30] D.P. Mohapatra, S.K. Brar, R.D. Tyagi, P. Picard, R.Y. Surampalli, Carbamazepine in municipal wastewater and wastewater sludge: ultrafast quantification by laser diode thermal desorption-atmospheric pressure chemical ionization coupled with tandem mass spectrometry, Talanta 99 (2012) 247-255.

[31] E.J. Routledge, J.P. Sumpter, Estrogenic activity of surfactants and some of their degradation products assessed using a recombinant yeast screen, Environ. Toxicol. Chem. 15 (3) (1996) 241-248.

[32] N.H. Tran, T. Urase, O. Kusakabe, Biodegradation characteristics of pharmaceutical substances by whole fungal culture trametes versicolor and its laccase, J. Water
Environ. Technol. 8 (2) (2010) 125-140.

[33] Y. Zhang, S.-U. Geißen, In vitro degradation of carbamazepine and diclofenac by crude lignin peroxidase, J. Hazard. Mater. 176 (1-3) (2010) 1089-1092.

[34] G. Cantarella, C. Galli, P. Gentili, Free radical versus electron-transfer routes of oxidation of hydrocarbons by laccase/mediator systems: catalytic or stoichiometric procedures, J. Mol. Catal. B: Enzym. 22 (3-4) (2003) 135-144.

[35] S.S. Bhattacharya, R. Banerjee, Laccase mediated biodegradation of 2,4-dichlorophenol using response surface methodology, Chemosphere 73 (1) (2008) $81-85$.

[36] R. Bourbonnais, D. Leech, M.G. Paice, Electrochemical analysis of the interactions of laccase mediators with lignin model compounds, Biochimica et Biophysica Acta (BBA) - Gen. Subj. 1379 (3) (1998) 381-390.

[37] S. Ostadhadi-Dehkordi, M. Tabatabaei-Sameni, H. Forootanfar, S. Kolahdouz, M. Ghazi-Khansari, M.A. Faramarzi, Degradation of some benzodiazepines by a laccase-mediated system in aqueous solution, Bioresour. Technol. 125 (2012) 344-347.

[38] G. Cantarella, F. d'Acunzo, C. Galli, Determination of laccase activity in mixed solvents: comparison between two chromogens in a spectrophotometric assay, Biotechnol. Bioeng. 82 (4) (2003) 395-398.

[39] M. Fabbrini, C. Galli, P. Gentili, Radical or electron-transfer mechanism of oxidation with some laccase/mediator systems, J. Mol. Catal. B: Enzym. 18 (1) (2002) $169-171$.

[40] G. Eibes, G. Debernardi, G. Feijoo, M.T. Moreira, J.M. Lema, Oxidation of pharmaceutically active compounds by a ligninolytic fungal peroxidase, Biodegradation 22 (3) (2011) 539-550.

[41] N. Golan-Rozen, B. Chefetz, J. Ben-Ari, J. Geva, Y. Hadar, Transformation of the recalcitrant pharmaceutical compound carbamazepine by pleurotus ostreatus: role of cytochrome P450 monooxygenase and manganese peroxidase, Environ. Sci. Technol. 45 (16) (2011) 6800-6805. 